Editors' Note: Rosenfield comments that Lu et al. may have been misled by the brain imaging findings in their study on people who stutter, especially when considering that stuttering is a response to an underlying abnormality and not the abnormality itself. Meyer agrees with the results of Poh et al. in their study of autonomic changes in seizures and discusses additional data that further explain the potential pathophysiology of sudden unexpected death in epilepsy. Ciceri expands on the hypothetical role of venous engorgement in the pathophysiology of Hirayama disease.

Chafic Karam, MD, and Robert C. Griggs, $M D$

\section{NEURAL ANOMALY AND REORGANIZATION IN SPEAKERS WHO STUTTER: A SHORT-TERM INTERVENTION STUDY}

David B. Rosenfield, Houston: The article by Lu et al. ${ }^{1}$ and accompanying editorial by Dr. Kell ${ }^{2}$ documented successful therapy for people who stutter by examining normalized brain imaging connectivity between the speech network and the supplementary motor area. They also examined decreased resting-state functional connectivity with the midline cerebellum.

The authors and the editorialist also studied brain activity at rest (not speaking) and provide insight into what might transpire in brain activity during a taskdependent state (speaking, fluently or otherwise). The obfuscating factor is that if stuttering is a response to an underlying abnormality and not the abnormality itself, then the meaning of the data should be questioned.

For example, it is possible that stuttering is the speaker's response to an instability in an altered speech-motor-auditory feedback loop. ${ }^{3,4}$ Improvement of stuttering behavior and output may be a valid finding, but only if improvement is a response to the underlying deficit causing stuttering and may not directly reflect any improvement in the deficit. The "core" of the stuttered response remains and may have nothing to do with the changes in imaging at rest, during speech, or following therapy.

(C) 2013 American Academy of Neurology

1. Lu C, Chen C, Peng D, et al. Neural anomaly and reorganization in speakers who stutter: a short-term intervention study. Neurology 2012;79:625-632.
2. Kell CA, Resting-state MRI: a peek through the keyhole on therapy for stuttering. Neurology 2012;79:615.

3. Nudelman HB, Hoyt B, Herbrich KE, Rosenfield DB. A neuroscience model of stuttering. J Fluency Disord 1989; 14:399-427.

4. Rosenfield DB. Stuttering and dysfluency. In: Stemmer B, Whitaker HA, eds. Handbook of the Neuroscience of Language, London: Academic Press; 2008:309-318.

\section{AUTONOMIC CHANGES WITH SEIZURES CORRELATE WITH POSTICTAL EEG SUPPRESSION}

Sascha Meyer, Homburg; Matthias Strittmatter, Merzig, Germany: In their study on potential contributing factors for sudden unexpected death in epilepsy (SUDEP), Poh et al. ${ }^{1}$ demonstrated that the magnitude of both sympathetic activation and parasympathetic suppression increased with duration of EEG suppression after tonic-clonic seizures.

Their findings suggest autonomic dysfunction as a pathophysiologic correlate of postictal EEG suppression, which may be vital to the concept of SUDEP. We agree with this concept but would like to add further data. It is likely that one of the most important mechanisms of SUDEP is cardiac arrhythmia precipitated by seizure discharge acting via the autonomic nervous system.

Generators of autonomic dysbalance include the insula, anterior cingulate gyrus, and ventromedial prefrontal cortex. ${ }^{2}$ Previous studies have demonstrated hemispheric lateralization in the control of the central autonomic nervous system, which is in large part mediated by the right insular cortex. ${ }^{2}$ In addition, cardiac autonomic control is under particular control of the right cerebral hemisphere. ${ }^{3,4}$ Moreover, clinical studies have also shown that profound desaturations below $90 \%$ were significantly correlated with hemispheric lateralization in localization-related epilepsy (odds ratio right vs left $=$ 2.098; 95\% confidence interval 1.078-4.085).5

The knowledge about lateralization of the anatomy and pathophysiology of the central autonomic nervous system may contribute to a better understanding of SUDEP and has the potential to detect patients who may be particularly susceptible to this devastating clinical entity.

(C) 2013 American Academy of Neurology

1. Poh MZ, Loddenkemper T, Reinsberger C, et al. Autonomic changes with seizures correlate with postictal EEG suppression. Neurology 2012;78:1868-1876. 
2. Meyer S, Shamdeen MG, Gottschling S, Strittmatter M, Gortner L. Sudden unexpected death in epilepsy in children. J Paediatr Child Health 2011;47:326-331.

3. Yoon BW, Morillo CA, Cechetto DF, Hachinski V. Cerebral hemispheric lateralization in cardiac autonomic control. Arch Neurol 1997;54;741-744.

4. Meyer S, Strittmatter M, Fischer C, Georg T, Schmitz B, Meyer S. Lateralization in autonomic dysfunction in ischemic stroke involving the insular cortex. Neuroreport 2004; 15:357-361.

5. Bateman LM, Li CS, Seyal M. Ictal hypoxemia in localization-related epilepsy: analysis of incidence, severity and risk factors. Brain 2008;131:3239-3245.

PEARLS \& OY-STERS: THE USE OF CT VENOGRAPHY IN HIRAYAMA DISEASE

Elisa F. Ciceri, Luisa Chiapparini, Alessandra Erbetta, Milan: Waung et al. ${ }^{1}$ described a case of Hirayama disease (HD) and concluded that CT venography may be helpful in evaluating patients in whom cervical MRI in flexion fails to demonstrate the typical features to clarify the pathogenesis of HD. Recently, the focus on the pathogenesis of HD seems to be shifting from arterial insufficiency to possible venous stagnation with impairment of spinal cord microcirculation. The hypothetic pathogenetic mechanisms of HD related to venous engorgement (VE) have been examined recently by Elsheikh et al. ${ }^{2}$ and by our group. ${ }^{3}$
In $\mathrm{HD}$, posterior VE during cervical flexion may be due to negative pressure in the posterior epidural space, impaired venous drainage in the jugular veins, or shifting of the blood from the anterior to the posterior epidural venous compartment. These conditions probably cause only a rerouting of the venous drainage without increase in venous pressure.

The only solid conclusion is that an inelastic dura and its slightly disproportionate growth respective to the bony canal ${ }^{4,5}$ cause a posterior VE that may affect spinal cord microcirculation.

(C) 2013 American Academy of Neurology

1. Waung MW, Grossman AW, Barmada SJ, Josephson SA, Dillon WP, Ralph JW. Pearls \& Oy-sters: the use of CT venography in Hirayama disease. Neurology 2012;79:e38-e40.

2. Elsheikh B, Kissel JT, Christoforidis G, et al. Spinal angiography and epidural venography in juvenile muscular atrophy of the distal arm "Hirayama disease." Muscle Nerve 2009;40:206-212.

3. Ciceri EF, Chiapparini L, Erbetta A, et al. Angiographically proven cervical venous engorgement: a possible concurrent cause in the pathophysiology of Hirayama's myelopathy. Neurol Sci 2010;31:845-848.

4. Patel TR, Chiocca EA, Freimer ML, Christoforidis GA. Lack of epidural pressure change with neck flexion in a patient with Hirayama disease: case report. Neurosurgery 2009;64:E1196-E1197; discussion E1197.

5. Toma S, Shiozawa Z. Amyotrophic cervical myelopathy in adolescence. J Neurol Neurosurg Psychiatry 1995;58:56-64.

\section{Neurology ${ }^{\circledR}$ WriteClick: Join the Debate!}

The editors encourage comments about recent articles through WriteClick:

Go to www.neurology.org and click on the "WriteClick" tab at the top of the page. Responses will be posted within 72 hours of submission.

Before using WriteClick, remember the following:

- WriteClick is restricted to comments about studies published in Neurology within the last eight weeks

- Read previously posted comments; redundant comments will not be posted

- Your submission must be 200 words or less and have a maximum of five references; reference one must be the article on which you are commenting

- You can include a maximum of five authors (including yourself) 


\section{Neurology}

\section{Autonomic changes with seizures correlate with postictal EEG suppression}

Sascha Meyer and Matthias Strittmatter

Neurology 2013;80;1538-1539

DOI 10.1212/01.wnl.0000429517.94343.7e

This information is current as of April 15, 2013

Updated Information \& Services

References

Permissions \& Licensing

Reprints including high resolution figures, can be found at: http://n.neurology.org/content/80/16/1538.2.full

This article cites 5 articles, 1 of which you can access for free at: http://n.neurology.org/content/80/16/1538.2.full\#ref-list-1

Information about reproducing this article in parts (figures,tables) or in its entirety can be found online at:

http://www.neurology.org/about/about_the_journal\#permissions

Information about ordering reprints can be found online:

http://n.neurology.org/subscribers/advertise

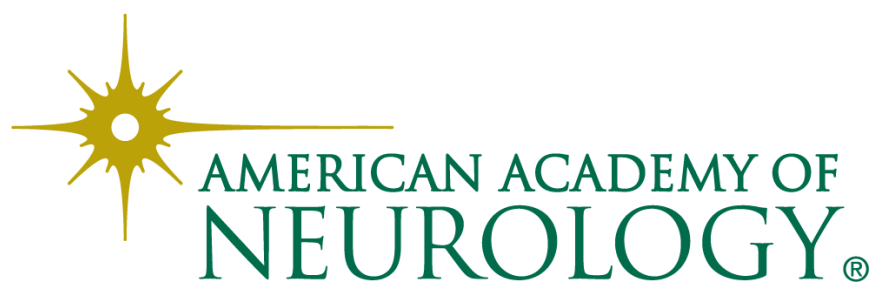

